\title{
Semiotics in Tengger Mask Puppet Show on Bethara Kala's Tale
}

\author{
Resdianto Permata Raharjo \\ Doctoral Program of Language and Literature Education, Surabaya State University, Surabaya, Indonesia
}

Setya Yuwana Sudikan

Language and Literature Education Study Program, Postgraduate School, Surabaya State University, Indonesia

Budinuryanta Yohanes

Language and Literature Education Study Program, Postgraduate School, Surabaya State University, Indonesia

\begin{abstract}
Tengger puppet mask contains a lot of semiotics. Semiotics consists of icons, indexes and symbols. Icons consist of (1) typology icons, such as mountains, oxen, vegetable plants (2) diagrammatic icons, such as the Ruler of Sang Sang Hyang Pikulun Sas Sis, Sang Hyang Punggung, Sang Hyang Pongat, Sang Hyang Lesmana Dewa, Sang Hyang Manikmaya, (3) metaphorical icons, such as Sang Hyang Punggung's sensing through the mediation of the jayengkaton story that the budama buddha is near Semeru Mountain. Index is a sign that indicates a natural relationship between signs and markers that are causal relationships, such as Sang Hyang Punggung's sensing through mediation of jayengkaton stories. While symbols are signs that do not show any natural connection between markers and their markings and have broad meanings, such as white pigeon, Bethara Guru, Bethara Kala. Keywords: Semiotics, icons, indexes, symbols, Tengger mask puppets, Bethara Kala.
\end{abstract}

DOI: $10.7176 /$ RHSS/9-12-14

Publication date:June $30^{\text {th }} 2019$

\section{Introduction}

Tengger community is one of the ethnic groups that live in the Tengger mountainous region which is very interesting and unique when viewed by their beliefs and cultures. They still believe in the existence of Gods who ruled the universe, believed in the spirits of their ancestors, and believed in the supernatural creatures who guarding Bromo and Semeru mountains.

One of the cultures of Tengger community that is still preserved up to now is Tengger mask puppet. Tengger mask puppet is a puppet performance art whose character is a human wearing a mask. Tengger mask puppet figure, although the character is human, they do not have any dialogue among each other figures. The figures only danced according to the contents of the story told by the puppeteer behind Tengger mask.

Tengger Mask Puppet is in Wonokerso Village, Sumber District, Probolinggo Regency. It still exists in the midst of the development of society in the technological era. The function of Tengger puppet mask is as entertainment and media for Ruwatan (ritual cleansing). Tengger puppet show is mystical and sacred and cannot be performed at any time or event.

The play on Tengger mask puppet show comes from the myth of Bromo Mountain and Bethara Kala. The tale of Bethara Kala contains a lot of mystical semiotics. Therefore, Tengger puppet show is examined using the semiotic theory.

Semiotics is a term put forward by Charles Sanders Peirce. Semiotics is the study of signs that have two-sided entities about signs, markers and meanings (Eco, 2016, p.19; Merrell, 1997, p. 13; Robinson, 2010, p. 15; Nurfaidah, 2016, p. 150). Semiotics is the study of signs and markers. Every sign, both verbal and nonverbal can be interpreted to find its meaning. According to Pierce, semiotics includes three aspects, namely icons, indexes, and symbols (Kaelan, 2009; Budiman, 2011).

Tengger mask puppet shows contain many signs. Signs are tools used for communication between two people to express something to someone else. Signs involve three aspects that work together, thus, one another cannot be separated. They are signs, objects, and interpretations. Signs can be used as representatives of something or someone in a certain capacity because of the representation relationship of an interpretant. A sign will be interpreted by means of another sign and so on (Eco, 2016: 21; Sahid, 2016: 5; Zoest, 1993; Berger, 2010). According to Pierce (Sahid, 2016: 5) sign refers to something called an object. The relationship between signs and references is divided into three, namely icons, indexes, and symbols.

Icon is signs whose reference has similar relationship. Icons can be classified into three, namely (1) typology icons, that refer to special similarities, such as maps and fashion sketches (2) diagrammatic icons, that have relational similarities, for example in official meetings seating is based on social status, and (3) metaphorical icons, that do not show the similarity on both the mark and the reference. The similarity is not between the sign and reference, but the two references which refers to the same sign. Example of the sign "kancil" refers directly to deer 
animals and clever humans. The two references have the same characteristics, namely cleverness (Sahid, 2016: 6).

Index is a sign that indicates a natural relationship between signs and markers that has causal relationships, such as smoke as a sign of fire. While the symbol is a sign that does not indicate the existence of natural relationship between the signs and the signified. The relationship is arbitrary and based on community conventions (Robinson, 2010: 118-119; Merrell, 1997: 52; Zoest, 1980: 8; Alex, 2006: 42; Supratno, 2010: 27; Fauzan, 2016; Rohima, 2017 ; Ratnaningrum, 2011).

\section{Research Method}

This study uses qualitative methods because this research is in the form of qualitative data of speech words and sentences used in Tengger Mask puppet show (Sudikan, 2014). The object of this research is Tengger puppet show, the play of Bethara Kala. Tengger mask puppet which playing Bethara Kala is very interesting because Tengger mask puppet can still live in the midst of Tengger people who live in remote areas on the top of Bromo mountain range called Puncak 30. Its location is in Wonokerso Village, Sumber District, Probolinggo Regency. To reach the location of the village, it must pass through the road that is very difficult and is still natural in the form of scattered stones. On the left and right, there are very deep gorges with a distance of 500-1000 m. The aim of Tengger puppet mask is in the framework of Ruwatan or ritual cleansing (Hommersley, 1995).

The data collection technique uses observation technique. It is taken from Tengger mask puppet show which is held overnight from around o'clock; 12.00 to 06.00 a.m., interviews with puppeteers, community leaders, recording, and taking notes.

Data analysis techniques uses descriptive analysis techniques and content analysis. The analysis procedure uses the stages of transcription, translation, classification, interpretation, and conclusion. The data validity testing technique uses triangulation, prolongs the period of research, peer discussions, seminars, and expert examinations (Creswell, 2015, Spradly, 1999).

\section{Findings and Discussion}

The Tengger puppet show contains a lot of semiotics. Semiotic is the one who learns the meaning and meaning. Semiotics includes indexes, icons and symbols. These three aspects will be explained one by one as follows:

\section{a. Icon}

Icons include three types, namely (1) typology icons, such as mountains, oxen, vegetable plants (2) diagrammatic icons such as the Ruler of the Sang Sang Hyang Pikulun Sas Sis, Sang Hyang Punggung, Sang Hyang Pongat, Sang Hyang Lesmana Dewa, Sang Hyang Manikmaya, (3) metaphorical icons, like Sang Hyang Punggung's sensing through the mediation of the jayengkaton story that the budama buddha is near Semeru Mountain. He immediately pursued, Sang Hyang Lesmana Dewa managed to capture the heirloom at the peak of Merapi. But because of mistakenly holding the left hand, suddenly the heirloom disappeared from Sang Hyang Lesmana Dewa's grasp.

\section{1) Typology Icon}

Typology icons are signs that refer to special similarities, such as mountain marks. Sign of the mountains, means that Tengger area is a mountainous area. The population lives in a mountainous area where the area is mountain, full of steep land, the slope is very sharp to a depth of 500-1000 m. The road is narrow, sometimes going up to 90 degrees. Sometimes it falls and turns very sharply. However, the area is fertile and is suitable for growing vegetables such as potatoes, cabbages, leeks, carrots and tomatoes.

Ox contains the meaning as a symbol of Mahesa Sura, the son of Jaka Seger and Rara Anteng who lives and controls Semeru Mountain. He has pets in the form of dark black ox which is very fat and strong as Mahesa Sura mounts. The spirit of this cow often enters the figure of Tengger puppet mask. If the oxen spirit of the Sura ox possessed the character of Tengger puppet mask, the character would have extraordinary power, jump from the stage to the audience and rage violently. For the suppression of the bull's anger, the oxen were held by five to ten people and taken to the garden or field. The bull's anger is wreaked in the garden or in the field. After being limp, then the ox is brought again to the floor. People who are exposed to masks or oxen spirit can also have extraordinary powers and rage violently. However, a shaman or puppeteer can heal.

Vegetables as a symbol of the main livelihoods and plants of Tengger people who inhabit Mount Bromo are vegetables, such as potatoes, cabbages, leeks, and carrots (Interview with Ki Lebari mastermind, May 27, 2018, in Wonokerto, Sumber, Probolinggo Village).

\section{a) Diagrammatic Icon}

The diagrammatic icon is a sign that has a relational resemblance, for example in an official meeting, the seating is arranged based on its social status. The Lord of Sang Hyang Pikulun Sas Sis is a diagrammatic icon. The Ruler of the Universe, Sang Hyang Pikulun Sas Sis refers to the creator and supreme ruler of the world. The data implies that there is no power that is more powerful or higher than the Ruler of the Jagad Sang Hyang Pikulun Sas Sis. He is the sole and supreme ruler. This can be seen in the data as follows:

The puppeteer opened the performance to recount the meeting of the Lord of the Jagad Sang Hyang 
Pikulun Sas Sis with his four sons namely; Sang Hyang Punggung, Sang Hyang Pongat, Sang Hyang Lesmana Dewa, Sang Hyang Manikmaya. Sang Hyang Sis Sis is talking about succession of heavenly leadership. Whoever from those four sons could bring home the Budama heritage which was intentionally thrown by Sang Hyang on Pawenang. Then he will the one who had the right to replace Pikulun at Pawenang as the ruler of the universe (WTT. II).

Based on these data, it is clear that the Lord of the Jagad Sang Hyang Pikulun Sas Sis is the single most powerful ruler in the world. He is talking about the succession of world leadership with his four sons. The Lord of Sang Hyang Pikulun Sas Sis is a sign that the ruler is very democratic. To replace him, instead of appointing one of his children, he chooses to make a contest. Whom among the four children can bring back the Buddhist heritage to heaven, he has right to replace the ruler of this world.

\section{b) Metaphorical Icon}

The metaphorical icon is a sign that does not show the similarity between the mark and the reference. The similarity is the two references which refer to the same signs (Sahid, 2016: 6). Data is taken from Klambi Limar Kinanti and Sakti Daludamana Belt. The data of "klambi Limar Kinanti" refers to the colored squares of black and white squares that means a hope of Semar's good, clean and honest serving to people, namely Pandawa Lima (Punta Dewa, Bima, Janaka, Nakula, and Sadewa). The sign "klambi Limar Kinanti" has no similarity to the reference, but has a similarity between the two references, namely having a clean feature.

Sakti Daludamana Belt data is a sign of state peace. If the Sakti Belt is loose, then the state is unstable or experiencing noise. Conversely, if the Sakti Daludamana Belt is tight, then the state is strong and stable. This can be seen in the data as follows:

Sang Hyang Lesmana Dewa mplayu-mplayu yerang Sang Hyang Manikmaya kanggo nuntut balas. Namung, nasipe pada karo kaloron kakange disabda dadi Dewa Wirati alias Kyai Semar Bojagati Nayantaka. Disangoni Klambi Limar Kinanti lan sabuk sakti Daludamana. Yen sabuk Semar kendor, gonjang-ganjing negara, sakwalike, yen kenceng, sentosalah Negara. Semar diutus tapa ana ing gunung Gamping lan yen wis mari, supaya menuju ke Klampisireng dadi pamong Pandawa. Sang Hyang Manikmaya menehi kendaraan Dara Putih (WTT.II.7).

(Sang Hyang Lesmana God ran around attacking Sang Hyang Manikmaya to take revenge. But his fate was the same as his two brothers and was said to be Dewa Wirati or Kyai Semar Bojagati Nayantaka. Equipped with clothes named Klambi Limar Kinanti and sakti Daludamana belt. If Semar belt is loosened, then the State breaks down. On the contrary, if it is tight, then it is the state is stable. Semar was told to meditate on Gamping Mountain and if it was finished so that Klampisireng became Pandawa's caretaker. By Sang Hyang Manikmaya, he was given the vehicle Dara Putih or white pigeon) (WTT.II.7).

The data contains a metaphorical icon, namely Dara Putih or white pigeon. The data has no resemblance to the reference. The data means goodness and holiness. Semar as a sign of a holy character, the vehicle must be holy too. It is symbolized by Dara Putih or white pigeon. In the life of Javanese and even Indonesian people, if you have a big celebration, it is usually marked by releasing white pigeons as symbol so that the intention of the celebration is good and holy and does not get any obstacles.

\section{b. Index}

Index is a sign that has a close relationship with the reference and has a causal relationship. Sample data is "Sang Hyang Punggung ngerti lewat lantaran cerita Jayengkaton yen pusaka budama ana ing cedake Gunung Semeru. Deweke terus ngejar"(WTT.II.2). ("Sang Hyang Punggung obeys through the intercession of the story of Jayengkaton that the budama heritage is near Semeru Mountain. He chased immediately") (WTT.II.2).

The data shows that the character of Sang Hyang Punggung has extraordinary magic or intelligence so that he can realize the existence of something through his inner eye. Although his eyes did not see the existence of a Buddhist heritage. However, he can see the existence of the Buddhist heritage through magic or intelligence. This can be seen in the data as follows:

"Papat putrane Pikulun Sas Sis gage goleki pusaka sakti budama kanggo prasyarat klungguhi tahta kahyangan/ kerajaan para Dewa. Sang Hyang Punggung mencium lewat perantaraan kisah jayengkaton yen pusaka budama ana ing cedak Gunung Semeru. Deweke terus ngejar" (WTT.II).

("The four sons of Pikulun Sas Sis rushed to find the magic heritage of the Buddha as a prerequisite for occupying the divine throne / kingdom of the Gods. Sang Hyang The back kissed through the mediation of the story of jayengkaton that the budama's heritage was near Mount Semeru. He chased immediately)" (WTT.II).

Based on these data, it shows the meaning that Sang Hyang Punggung has ambitions to be able to take power in place of his father and has extraordinary intelligence. He does not have a good strategy and does not have patience in achieving his ideals to replace his father's power. The word "hurrying" contains the meaning of Sang Hyang Punggung lustful or ambitions to be able to immediately bring back the Buddhist heritage to heaven so that he can immediately replace his father's power as the ruler of this world.

Different from his younger brother, Sang Hyang Manikmaya, was patient and had a good strategy. He did not 
rush to immediately get a Buddhist heritage, but instead he meditated and prayed for inner blessing to his mother. He finally got a wangsit or sasmita / unseen sign in order to meditate in the sorban forest at Goa Paseban Gandamayit. Finally, it was he who can find and bring the Buddhist heritage to Heaven and succeeded in replacing his father's position as the ruler of this world. This can be seen in the data as follows:

Beda karo telu kakange sing terkesan brangasan lan kebak nafsu kanggo nemoake pusaka Budama, putra papat Pikulun Sas Sis yaiku Sang Hyang Manikmaya duweni strategi sing beda. Deweke nyeluk namane ibue (nyambat) lan njaluk doa restu sarana batin. Dumadakan deweke oleh sasmita/tanda gaib supaya tapa ana ing alas sorban siluman, sorban=udeng/ikat kepala, siluman=makhluk halus. Pase ana ing Paseban Gandamayit .... (WTT.III.3)

(Other than his three brothers who seemed to be full of lust or ambition of Budama, Pikulun Sas Sis's fourth son, Sang Hyang Manikmaya, took a different strategy. He called his mother's name (nyambat) and asked for inner blessings. Suddenly he got the sasmita / magic sign to meditate in the forest of Sorban, Sorban $=$ udeng $/$ headband, stealth $=$ ghost. Precisely at the Paseban Gandamayit cave....) (WTT.III.3).

The data shows the meaning that to achieve something, it must not to be taken by lust and haste, but by fully patience, caution and consideration in order to achieve what is aimed. To achieve something based on lust and haste, it will harm itself and consequently, you cannot achieve what it aspires to. The most important thing to do to achieve something is asking the parent's blessing. If parent already know and pray, it will be easier to achieve what they aspire to. The blessings and prayers of both parents are very important for a child who will achieve his goals. By blessings and prayers of his parents, finally Sang Hyang Manikmaya got a wangsit or unseen signal, so that he could meditate in Goa Paseban Gandamayit. By meditating in Paseban Gandamayit Cave, Sang Hyang Manikmaya easily obtained a Buddhist heritage because the inheritance was delivered by Betara Narada, Betara Surya, and Betara Yamadipati. Even though should finish the test first, Sang Hyang Manikmaya could pass the exam of those three Gods. The heirloom heritage of the religion was left to Sang Hyang Manikmaya.

Sang Hyang Manikmaya immediately goes back to his father and is welcomed with joy by Pikulun Sas Sis for succeeding in getting a Buddhist heritage. Then told to wash his hair and given white clothes as a sign of the God's clothes, for a symbol of the holy person. Sang Hyang Manikmaya was finally appointed as head of the God in his father's palace/heaven and was given the title Bethara Guru. Bethara Guru was given a pethetan / garden of heaven and was advised by his father while being the head of the God. "It must not be adigang-adigung-adiguna, arrogant and conceited. Do not insult the poor woman who will come to him and will become his soul mate". This can be seen in the data as follows:

"Ora oleh adigang-adigung-adiguna, sombong dan tinggi hati. Ora oleh ngina wong wedok miskin sing besuk bakal teka menyang seliramu lan arep dadi jodohmu)" (WTT.III.4).

("May not be adigang-adigung-adiguna, arrogant and conceited. Do not insult the poor woman who will come to you and will become your soul mate)" (WTT.III.4).

Based on the data, it can be concluded that Sang Hyang Sis advises his children who have been appointed as Bethara Guru, if being a leader he should not to do tyranny to other people, he should not be arrogant, should not insult poor women who will come to him and will become his soul mate. The data also implies that the change of the prospective leadership must be based on competence, patience, morals, and politeness, not based on mere descent, ambition, and money as is in many societies case today. The model of leadership change can be an example in a government system or kingdom that occurs in the community so that the change of leadership can run peacefully.

c. Symbols

Tengger puppet mask show contains many symbols, such as Dara Putih or white pigeon. Dara Putih or white pigeon is a symbol that means purity and kindness. The symbol of the white pigeon which means purity and goodness has been agreed conventionally by most people, Tengger community in particular and the Indonesian people in general. If they want to have a big celebration, generally they will release white pigeon as a symbol of good and holy intention so that in carrying out the celebration there is no obstacle and is facilitated by God. The white pigeon is usually released to fly according to his will.

Bethara Guru, as a symbol of a head of God who cannot restrain his lust when he is with the beautiful woman Nagagini, so the sperm comes out and eventually becomes Bathara Kala.

Bathara Kala is also a symbol of evil. The illegitimate child symbol that is not recognized as his child by his father, Bethara Guru, because Bethara Kala was not born from his mother's womb, but it happened because of Bethara Guru's semen that came out because she could not hold his lust while he is together with Nagagini. Bathara Guru does not want to admit Bethara Kala as his child. However, when Bethara Kala was looking for his father and mother, he met Bethara Narada and was told that Bethara Kala's father was Bethara Guru and his mother was Naga Gini. Bethara Kala faces Bethara Guru and Naga Gini, but Bethra Guru still does not want to admit Bethara Kala as his child. Bethara Kala insisted in order he could be recognized as his child. Finally Bethara Guru wanted to admit Bethara Kala as his child. But he provided requirement to be fulfilled by Bethara Kala, meditating in Peak 
B 29 (the famous peak of Mount Bromo called Puncak B29) and was given a keris heirloom named Budama. Finally, Bethara Kala was able to meditate to fulfill Bethara Guru's request.

Betari Durga is a symbol that firstly contains very beautiful angel reference, became the wife of Bethara Guru who became the head of the god, but then her character was not good. As a mother, she cannot educate her child, Bethara Kala, well. Letting her children's appetite to provide human food, such as ontang-anting, sendang kaapit pancuran, pancuran kaapit sendang, people walking in the midst of noon. So, she is cursed by Bethara Guru to be a bad woman with a giant face and become the queen of demons. This can be seen in the data as follows:

"Nagagini dimarahi Bethara Guru karana ora ngendekna kelakuan elek lan dikutuk dadi Bethari Durga lan manggon ana ing kahyangan Dandang manguri menjadi ratu para setan” (WTT.XII).

("Nagagini was scolded by Bethara Guru for not stopping her child bad deeds and then being cursed to become Bethari Durga and dwelling the Kandang Dandang manguri becoming the queen of the demons") (WTT.XII).

Based on these data, Bethari Durga is a symbol of women who are not good and cannot educate her children. Her child asked for whatever he obeyed even though he asked for something that was not good, and could not control her son's evil desires. Goddess Durga became the queen of the demons. She was a beautiful woman and wife of God's head, but she still committed many crimes. Finally, Bethara Guru cursed Bethari Durga, becomes a giant who had an ugly face and had bad characters.

\section{Conclusion}

Based on the description above, it can be concluded that Tengger mask puppet shows contain a lot of semiotics. Semiotics in Tengger puppet mask show includes three aspects, namely icons, indexes, and symbols. Icons consist of three types, namely typology icons, diagrammatic icons, and metaphorical icons. Typological icons such as mountains, oxen, and vegetables. Diagrammatic icons such as the position of Sang Hyang Sas Sis with his four children. Metaphorical icons like Klambi Limar Kinanti and Sakti Daludamana Belt and White Pigeon. An index is a sign that has a close relationship with the reference. Examples of Sang Hyang Punggung's sensing the intercession of the story of Jayengkaton that the budama heritage is near Semeru Mountain. He chased immediately. Symbols are signs that have no connection with their references and have been formed conventionally and have broad meanings, such as Bethara Guru, Bethara Kala, white pigeon, Sang Hyang Sis, and Semar.

\section{References}

Alex, Sobur. 2006. Semiotika Komunikasi. Bandung: Remaja Rosdakarya.

Bahaudin. 2015. Mistik dan Politik: Praktik Perdukunan dalam Politik Indonesia.Universitas Bayangkara Jakarta Jaya: Jurnal Keamanan Nasional, Vol. 1, No. 3.

Berger, Artur Asa. 2000.Tanda-tanda dalam Kebudayaan Kontemporer. Yogyakarta: PT. Tiara Wacana Yogya. Budiman, Kris. 2011. Semiotka Visual, Konsep, Isu, dan Problem Ikonisitas.Yogyakarta. Jalasutra.

Creswell, John W. 2015. Research Design, Penedekatan Kualitatif, Kuantitatif, dan Mixed (edisi ke-5). Yogyakarta: Pustaka Pelajar.

Eco, Umberto. 2016. Teori Semiotika, Signifikasi Komunikasi, Teori Kode, Setra Teori Produksi-Tanda (Terjemahan Insiak Ridwan Munsir). Bantul: Kreasi Wacana Offset.

Fauzan. 2016. Makna Simbolik Topeng Sakura Pada Masyarakat Adat Lampung. Kalam: Jurnal Studi Agama dan Pemikiran Islam: Vol 10, No 1, Juni 2016.

Grertz, Clifford. 2017. Agama Jawa Abangan, Santri, Priyai dalam Kebudayaan Jawa. Depok: Komunitas Bambu. Hammersley, M., \& Atkinson, P. 1995. Ethography: Principles In Practice (edisi ke-2). New York: Routledge.

Kaelan. 2009. Filsafat Bahasa Semiotika dam Hermeneutika. Yogjakarta: Paradigma.

Merrell, Floyd. 1997. Peirce, Signs, and Meaning. Toronto Buffalo London: University of Toronto Press.

Nurfaidah, Resti. (2016). Adinda dalam Keterbacaan Simbol. Jurnal Bebasan, Vol.3, No.2, Desember. 148-159.

Rahima, Ade. 2017. Interpretasi Makna Simbolik Ungapan Tradisional Seloko Hukum Adat Melayu Jambi. Jurnal Ilmiah Universitas Batanghari Jambi: Vol 17, No1, Tahun 2017.

Ratnaningrum, Ika. 2011. Makna Simbolik dan Peranan Wayang topeng Endel. (http://journal.unnes.ac.id/nju/index.php/harmoni/jurnal pengetahuan dan pemikiran seni/11(2)(2011):125129).

Robson, SO. 1994. Prinsip-Prinsip Filologi Indonesia. Jakarta: Rul.

Sahid,Nur. 2016. Semiotika untuk Teater, Wayang, Wayang Purwa, dan Film. Semarang: Gigih Pustaka Mandiri. Sudikan. 2014. Metode Penelitian Sastra Lisan. Surabaya: Pustaka Illang.

Supratno, Haris. 2010. Sosilogi Seni, Wayang Sasak Lakon Dewi Rengganis dalam Konteks Perubahan Masyarakat di Lombok. Surabaya: Unesa University Press.

Supratno, Haris. 2015. Sosiologi Seni, Foklor Setengah Lisan Sebagai Media Pendidikan Karakter Mahasiswa. Surabaya: Unesa University Press.

Spradley, James P.. 1997. Metode Etnografi. Yogya: PT. Tiara Wacana. 
Wanulu, Rukyah. 2016. Makna Interaksi Simbolik Pada Proses Upacara Adat Cumpe dan Sampua Suku Buton di Samarinda. eJournal Ilmu Komunikasi, 2016, 4 (3): 265-279 ISSN .2502-597x, ejournal.ilkom.fisipunmul.ac.id.

Zoest, Aaart Van. (1993). Semiotika. Jakarta: Yayasan Sumber Agung 